\title{
PEDAGOGY
}

\section{PEDAGOGICAL PLATFORM FOR THE DEVELOPMENT OF PROFESSIONAL AND SPIRITUAL QUALITIES OF FUTURE DOCTORS}

\author{
Ahmedova N. D. \\ Uzbekistan Andijan State Medical Institute, Uzbekistan \\ DOI: https://doi.org/10.31435/rsglobal_wos/31032020/7006
}

\section{ARTICLE INFO}

Received: 12 January 2020

Accepted: 11 March 2020

Published: 31 March 2020

\section{KEYWORDS}

professional qualities, spirituality, education, morality, deontology, specialist, doctor, medical practice, ethics, moral. \begin{abstract}
The article considers the effective impact of professional and spiritual qualities on the life of society in the future, and in connection with this the need to improve the educational system in higher educational institutions and expand its methodological support. It is also said that the development of professional and spiritual qualities of students of medical universities is a complex, lengthy and consistently developing process that requires the cooperation of all participants in the educational process - the teaching staff and students.
\end{abstract}

Citation: Ahmedova N. D. (2020) Pedagogical Platform for the Development of Professional and Spiritual Qualities of Future Doctors. International Academy Journal Web of Scholar. 3(45). doi: 10.31435/rsglobal_wos/31032020/7006

Copyright: (C) 2020 Ahmedova N. D. This is an open-access article distributed under the terms of the Creative Commons Attribution License (CC BY). The use, distribution or reproduction in other forums is permitted, provided the original author(s) or licensor are credited and that the original publication in this journal is cited, in accordance with accepted academic practice. No use, distribution or reproduction is permitted which does not comply with these terms.

Healing is a professional activity based on humanistic principles. This is evidenced by a number of accepted international legal normative documents on deontology and ethics of doctors. These include the Geneva Declaration (1948), the Geneva Oath, the International Code of Medical Ethics (1949), the Helsinki-Tokyo Declaration (1964, 1975), the Sydney Declaration (1969), the Edinburgh Declaration of the World Federation of Medical Education (1988).

Among the main tasks of educational work in the pedagogical paradigms of developed countries, the demand for professionally - spiritual qualities and competencies of students is growing. Developed on integrated basis, the formed professional and spiritual qualities have an effective impact on the life of society in the future, which is ensured in the harmony of higher education and upbringing.

In addition to the effective work carried out in this direction, there is a need to improve the system of educational work in higher educational institutions and expand its methodological support.

The Strategy of Actions for Further Development of the Republic of Uzbekistan defines the direction of "spiritual and educational development of youth" [1], thereby, the development of spiritual and moral relationships and skills of students becomes relevant. Large-scale spiritual reforms carried out by the President of the Republic of Uzbekistan Sh.M. Mirziyoyev, Development Strategy of Uzbekistan, accelerating reforms in the framework of the Concept for the Development of Higher and Secondary Specialized Education until 2030,the increasing demands for the spirituality of modern specialists are determined by the requirements to increase the moral level of future public servants, service sectors and social workers in general.

Professional and spiritual qualities is a cluster of unique personal qualities that are determined by a specific area, the requirements of a specific professional activity.

The object of doctor's activity is a person. And man is the highest and unique value among all the values in the world, and this is confirmed by our national spirituality, the Constitution of the 
Republic of Uzbekistan, as well as the adopted laws. And this is clearly manifested as the main principle of medical deontology, the humanistic development of the future physician's spirituality as the basis of his professional activity.

According to the requirements of Article 44 of the Law of the Republic of Uzbekistan "On the Protection of Citizens' Health", the oath of the doctor of the Republic of Uzbekistan includes a number of moral and ethical requirements for the spirituality of doctors. Today, the "Oath" performs its important professionally - spiritual function and serves as a moral factor in maintaining the health of our people.

The degree of study of the problem. Theoretical, socio-political, philosophical, ideological, sociological aspects of student education were studied by Azimova Z.E., Akramova Sh.A., Alliyarov A.D., Aleuov U., Asadov Yu.M., Egamberdieva N.M., Bekmuradov M., Zhakbarov M., Kakhkhorova M., Tulenova G.Zh., Kuronov M., Musurmonova O., Nazarov K., Mustafaev Sh., Makhkamov U., Kosimova Z., Kuranboyev K., Makhmutova G.I., Khojaev B., Utebaev T.

Over the years of independence in our country the following shave been investigated:the pedagogical management system for the formation of the professional orientation of future medical workers by F. Ziyaeva, the issues of the professional competence formation of students of medical colleges by Yu. E. Rakhimova. The issues of diagnosis motivation of educational activity of medical students have been investigated by the psychologist G.D.Kuldasheva.

In this regard, in 2014, A. Usmankhodzhaev's manual "The Spirituality of Medical Workers" [3] was published. However, despite the growing importance of the relevance of issues of spirituality, national ideology, the study of the problems of spirituality of future medical specialists and their improvement at medical universities has not been separately studied in our country as a socio-pedagogical problem.

The researches of the scientists of the CIS countries Kotova I.B., Slastenina V.A., Maksimova V.N., Nikandrova N.D., Shiyanova E.Kh. etc. emphasize the strengthening of professional identification with personal motives, feelings, ideals, profession and activity in the pedagogical process.

In pedagogical science, upbringing is interpreted as cultural identification, the process of pedagogically controlled social adaptation, the disclosure of the individual's creative talents and their direction (Asmolov A.G., Berulava M.N., Bratchenko S.L., Vulfov B.Z., Gavrilovets K. V., Novikova L.I., Selivanova N.L.). This understanding of the phenomenon of education is reflected in the form of professional education in the professional sphere. However, the above studies did not address the issues of professional spirituality and spiritual qualities of future doctors.

The analysis of modern research works shows that in the development of professional spirituality of future doctors there are some scientific and pedagogical contradictions.

Including;

- underdevelopment in the pedagogy of theoretical foundations and practical methodological aspects in the context of various industries, the need to educate professional spirituality in every future highly qualified specialist;

- the growing demand in medical practice for a doctor with high professional and spiritual level, and at the same time, insufficient scientific and methodological support in the theory and practice of training future doctors.

The presence of these problems necessitated the identification of pedagogical conditions for the training of highly qualified doctors with professional and spiritual qualities and their introduction into medical universities.

In order to solve those problems, we formulated the research topic as follows: "Pedagogical platform for the development of professional and spiritual qualities of future doctors."

The object of the study: the process of educational and spiritual activities in medical universities.

The subject of the research: pedagogical conditions for the development of professional and spiritual qualities of future doctors at medical universities.

Research Objectives:

1. Disclosure of theoretical and methodological foundations of the process of development of professional and spiritual qualities of future doctors at higher medical schools;

2. Determination of the resources of higher medical educational institutions for the development of professional and spiritual qualities of future doctors; 


\section{Scientific novelty of the research work}

- The matrix of professional and spiritual qualities of future doctors through pedagogical content integration is defined and a mechanism for the development of professional and spiritual qualities is developed;

- The content of educational, spiritual and educational work at higher medical educational institutions of the Republic of Uzbekistan is enriched with ethical components of the Geneva Declaration of the World Medical Relief (WMR);

- a set of pedagogical conditions is substantiated that ensures the development of professional and spiritual qualities of future doctors and methodological recommendations for their implementation are developed.

\section{Scientific and practical significance of the research results.}

The theoretical value of the study lies in the fact that, based on the analysis of the work of al-adab (pedagogical) thinkers, enlightening ideas of Abu Ali ibn Sina, the possibilities of the historical and medical heritage in the development of spiritual and moral qualities of future doctors have been revealed;

The content of the development of professional and spiritual qualities of the students of medical universities is determined by identifying a matrix of professional and spiritual qualities on the example of the content integration of the oath of the doctor of Uzbekistan and the rules of ethics and behavior of Andijan State Medical Institute, development of criteria, indicators of professional and spiritual qualities, as well as enriching them with theoretical, historical examples and approaches, revealing the role and importance of professional and spiritual qualities in the formation of the goals of medical activity;

The practical significance of the study is determined by clarifying the pedagogical and psychological features of the development of professional and spiritual qualities of future doctors, determining the parameters, stages that make up the pedagogical support of this complex of professional and spiritual qualities, improving the content, forms and technologies of spiritual and educational work to develop spiritual and moral qualities of future doctors, the development of scientifically based proposals and recommendations for the implementation of historical and medical heritage into modern system of higher medical education on the principle of "spiritual medicine";

The Edinburgh Declaration of the World Federation of Medical Education (1988) states that every patient should be able to see the image of a doctor, an attentive interlocutor, a sensitive observer, a competent doctor and a very courteous person.

Unfortunately, in recent years, a decline in professional and spiritual qualities has been observed in the relationship between the doctor and the patient, and there are tendencies to consider the patient as a passive object. Nevertheless, the triad founded by Abu Ali Ibn Sina, "when treating the patient, first of all, use the power of the word, if the word is not enough, use medicinal herbs and, last but not least, use the scalpel" remains an axiom in modern world medicine.

In communicating with the patient, the doctor should help to overcome his fear and get rid of doubts arising before making a responsible decision, to calm and give hope for recovery. That is why the famous doctor V.M. Bekhterev said, "if the patient does not feel relief after talking with the doctor, he is not a doctor. He must leave the medical profession. "[14] It follows that the ability to inspire people should be professional and spiritual quality of every doctor.

Researchers N.V. Kudryavaya, E.M. Ukolova, A.S. Molchanov and others in the study guide "Doctor-teacher in a changing world. Traditions and innovations "provide examples of the qualities of real doctors, above all, the humane treatment of the patient, responsibility, impartiality, honesty, modesty, hard work, culture, cooperation and the desire to constantly improve their knowledge. "One of the indicators of the skill of a modern doctor is the spiritual and moral aspect of his medical activity," as the researchers N.V. Curly, E.M. Ukolova, A.S. Molchanov and others think. "A low level of moral and ethical culture inevitably leads to a deterioration in the ethics of professional thinking and the activities of doctors. This is manifested in three forms - in the social relationship of the doctor with the patient; in violation of the doctor-patient relationship model; in medical and deontological violations. Since the personal qualities of specialists working with people are not inferior to their theoretical knowledge and skills. Here the difference between professional and personal qualities is conditional" [7]. 
In the relations of social life, there are several types of corporate and professional ethics such as "Judicial Spirituality", "Teacher Ethics", "Ethics and Rules of Conduct for the Internal Affairs Officer", and "Engineer Ethics", which are important in the spiritual and moral relationships in the society. However, in life there are such vices as a contradiction to professional and spiritual qualities, going beyond normal behavior, immorality, corruption, rudeness, bureaucracy and deceit. The future doctor - student as an adult person is ready to develop their positive qualities and get rid of negative ones in the process of self-education and self actualization. The great doctor Abu Ali ibn Sina said: "If a person cannot get rid of chatter, confrontation, contention, complaints, discontent, gossip, he will not be able to get rid of his dirty and lower nature"[15]. This conclusion is confirmed by the results of modern research.

According to the study conducted by psychologist G. Kuldasheva at Samarkand State Medical Institute in the study of student motivation, "personal qualities play a key role in shaping the motivation of educational activities of students of medical universities. The relationship of the sustainability of the motivation of educational activities of an individual with his level of interest and the formation of various points of view, the importance of the component of self-awareness and selfesteem of the individual in creating educational motivation, as well as social and personal motives, are shown as important factors in the development of educational motivation." [6]

At present, the axiological aspect of the problem is of great importance. That is, "... the training of axiology basis is very important. For this reason, this is one of the main criteria for the effectiveness of education - the use of those areas of knowledge in which achievements in the field of universal values are summarized" [9], says K. Nazarov, Doctor of Philosophy.

This comes out from the differences in national, historical traditions and lifestyle of each country. For example, in the United States the most important task of upbringing is the formation of consciousness of national pride and statehood. In Britain, education is primarily aimed at preserving the traditional values and spiritual foundations of the society. Comparing the education systems of developed countries (England, America), we identified the following common aspects. An active civic stand, high spirituality and spiritual values remain at the forefront of educational values. The preservation and training of these values is the central task of the educational policies of these countries. For example, the law of the United States of America (The Student Citizen Act) addresses the question of what qualities of a modern student should be inculcated [16].

Abu Ali ibn Sina said that things in the world, including human qualities, can be divided into three levels, that is, the highest level - the means leading to perfection; insufficient funds to achieve excellence and, finally, intermediate means. This scientist, a thousand years ago, substantiated the idea of measuring the human, professional qualities of education and development from the point of view of philosophy and theoretical pedagogy. Ibn Sina does not consider the intrinsic beauty and inferiority inherent in man as the inevitability of fate, which cannot be corrected. Rather, he seeks to identify the causes of these traits: something external from his environment affects the appearance of good and bad behavior in people. This effect can be either negative or positive. By eliminating the causes of negative influences, one can form good manners and behavior in a person. The purpose and essence of the education of needs (NAFS) is to solve this problem [5].

Alisher Navai in his work "Love of Hearts" ("Mahbubul - kulub") says: "An experienced and merciful healer is like Jesus. The work of Jesus is to return the soul that has left the body with prayer, and the task of the healer is to prevent the soul from leaving the body with the help of healing. The face of such a doctor is loved by the sick people, and the words are pleasant. His every breath is a cure for the sick person; every step is healing the disease. His face resembles the savior of Khizr, and the decoction that he gives is life-giving water. Even if the doctor is a master of his craft, but at the same time ill-mannered, insensitive and rude, he will not be able to heal the patient and his body, regardless of the medical procedures. A friendly doctor is a cure for bodily ailments, but a cruel, vicious and illiterate doctor is a disaster for people:

Хозиқ табиби хушгуй тан ранжиға шифодур,

Омию тунду бадхўй эл жониға балодур”[2].

Professional and spiritual qualities determine the norms of the cognitive-behavioral system, regulating pedagogical activity, act as a mediator and a link between pedagogical activity and the social worldview. 
The acquisition of pedagogical values occurs in the process of the implementation of pedagogical activity, and in this process their subjectivation is carried out. The level of subjectivity of values is a sign of professional development of the individual[10].

S. Mustafayev, a researcher separately emphasizing the professional and personal qualities of the head of the art circle, said that "he should be an organizer, teacher and speaker with a high national ideological consciousness, educated in the theory of education, methodology, psychology and knowledge of national and local culture, history" [8].

Akramova Sh. A. examines the ideological immunity of a customs officer as professional and spiritual qualities of a person and concludes that ".... spiritual and ethical qualities like honesty, integrity, impartiality, dedication, patriotism, required from customs officers, have not changed for millennia"[11].

I.N. Aslanov emphasizes the important role of courtesy as a quality in overcoming psychological barriers and obstacles in the professional activities of a customs officer in his candidacy work [12].

Yu.M. Asadov a psychologist, speaking about the communicative readiness of a modern specialist, comes to the conclusion that this quality promotes empathy, courtesy, friendship, cooperation, collectivism, willingness and ability to interact with colleagues, avoiding unnecessary tension in relationships, the ability to solve problems, and the ability to compromise with colleagues [13].

Another important condition for the success of a future doctor is not only his professionalism, but also his personal, spiritual maturity and competence - the possession of relevant social competencies. In this case, the physician's spiritual maturity works as a catalyst to activate initial training. Therefore, future doctors need to develop the necessary spiritual qualities for professional work at the medical institute. Because due to insufficient spiritual control over their professional behavior and activities, even highly qualified specialists can be deceived by the ideas of corruption, crime, fraud, cosmopolitanism, selfishness, commercialism and even religious extremism, and can lead to actions against themselves, people, people and state.

The content analysis of professional and spiritual qualities in the text "Oaths of a Doctor of the Republic of Uzbekistan" reveals the conditions for creating a cluster of spiritual and ethical qualities such as responsibility, humanism, tolerance, dedication, commitment, simplicity, modesty, honesty, perseverance, willpower, kindness, and pedagogical skills, respect for teachers, respect for professional and spiritual traditions, loyalty.

A cluster of these qualities forms the basis of the work carried out in the experimental work. This cluster of moral and ethical qualities can be called "doctor etiquette." However, due to the fact that etiquette is mainly limited by the person-to-person communication system and is not included in its attitude to work, duties and social duty, we interpret this as a set of professional moral qualities, and at the same time we consider it necessary to study and enrichment with world spiritual and ethical standards.

In particular, the "Solemn Oath of the Doctor" was adopted at the 2nd General Assembly of the World Medical Association, held in Geneva in September of 1948, at the 22nd meeting of the World Medical Assembly in Sydney, Australia, in August 1968, supplemented at the 35th meeting of the World Medical Assembly, held in Venice, Italy, in October of 1983, supplemented, at the 46th meeting of the World Medical Assembly in Stockholm, Sweden, in September of 1994, supplemented, and is currently active worldwide.

The pedagogical platform for the development of professional and spiritual qualities in medical universities and its capabilities were studied by us on the basis of the analysis of moral and ethical content analysis.

As part of the study, a matrix of professional and spiritual qualities of future doctors was determined in the context of the content integration "The Oath of the Doctor of Uzbekistan" and "Ethical Rules of Andijan State Medical Institute", and development criteria and diagnostic indicators of professional and spiritual qualities of future doctors were developed.

Our studies have shown that the content of these documents is built in projective and preventive direction. In other words, the being presented by us 43 signs are projective, that is, they are intended for development, and in 52 negative qualities the pedagogical preventive tasks are provided. 
Matrix of professional and spiritual qualities of future doctors

On the example of pedagogical content integration "The Oath of the Doctor of Uzbekistan" and "Ethical Rules of Andijan State Medical Institute"

\begin{tabular}{|c|c|}
\hline $\begin{array}{l}\text { Positive professional and spiritual } \\
\text { qualities }{ }^{1}\end{array}$ & Negative professional and spiritual qualities \\
\hline $\begin{array}{l}\text { selflessness, justice, modesty, relevance, } \\
\text { kindness, pedagogical skill, respect for } \\
\text { teachers, respect to professional and } \\
\text { spiritual traditions, loyalty, sense of } \\
\text { responsibility, correct understanding of } \\
\text { the state's internal and foreign policy, } \\
\text { patriotism, humanity, initiative, } \\
\text { entrepreneurship, will, faith, conscience, } \\
\text { moral immunity, mutual trust, respect, } \\
\text { caring for each other, solidarity, unity, } \\
\text { attentiveness,friendship,honesty, justice, } \\
\text { image, interpersonal behavior, delicacy in } \\
\text { communication, struggle with the } \\
\text { consumption and distribution of narcotic } \\
\text { and psychotropic substances, alcohol and } \\
\text { tobacco, the pursuit of excellence, honest } \\
\text { life, unity, hard work, care, tolerance, the } \\
\text { desire for harmony, humanism. }\end{array}$ & $\begin{array}{l}\text { Violence, obscenity, cruelty, alcoholism, drug } \\
\text { addiction, religious extremism, "popular culture", } \\
\text { infringement of individual rights, slander, insult, } \\
\text { ignoring ethics, attending classes in religious clothes, } \\
\text { in open clothes that attract people's attention, also in } \\
\text { tight clothes, wear metal chains, brooches, various } \\
\text { tattoos, sportswear and shoes, posting on the Internet } \\
\text { information contrary to national and universal values, } \\
\text { production, storage, distribution of illegal religious } \\
\text { information, obscene images, propaganda of national, } \\
\text { racial, ethnic or religious hatred, offense, } \\
\text { dissemination of information causing moral or material } \\
\text { damage to a team member, bodily harm, drugs, } \\
\text { psychotropic drugs, smoking, domestic violence, } \\
\text { contention, gambling and other risk-based games, } \\
\text { humiliation of others, appropriation of the intellectual } \\
\text { property of others, use of rude, obscene expressions, a } \\
\text { fight, causing moral, material or physical harm to } \\
\text { others, timely informing relevant organizations about } \\
\text { cases of violation of the legislation of the Republic of } \\
\text { Uzbekistan, rudeness towards teachers, talking during } \\
\text { classes; discussion of grades of other students with the } \\
\text { teacher; any manifestation of lies, deceit or misleading } \\
\text { actions; disrespect for employees and their comrades; } \\
\text { to receive outside help in passing the current, final } \\
\text { control, written work, assignment of work performed } \\
\text { by other people; skipping or being late for classes; } \\
\text { leave the audience without the permission of a } \\
\text { professor or teacher; intentional obstruction to the } \\
\text { efforts of another student; showing his material } \\
\text { superiority. }\end{array}$ \\
\hline
\end{tabular}

The spiritual and moral qualities of a doctor not only solve the medical problems of patients, but also satisfy their needs for compassion and human kindness.

Therefore, the development of professional and spiritual qualities of future doctors requires an understanding of the continuous process of pedagogical influences aimed at developing in students a conscious attitude to the necessary spiritual and ethical standards and a set of professional qualities in the process of solving professional problems.

Conclusions. In conclusion we can say the development of professional and spiritual qualities of students of medical universities is a complex, lengthy and consistently developing process that requires the cooperation of all participants in the educational process - the teaching staff and students. The effectiveness of this process, first of all, is achieved due to the scientific validity of educational work, systematicity, creativity, spiritual and educational basis and the effectiveness of educational activities, creating the most favourable conditions for the spiritual and moral development of students.

\footnotetext{
${ }^{1}$ Italics - qualities not mentioned in the oath. The bold quality mentioned in the oath.
} 


\section{REFERENCES}

1. Decree of the President of the Republic of Uzbekistan dated February 7, 2017 N UP-4947 "On the strategy for the further development of the Republic of Uzbekistan". - Collection of Laws of the Republic of Uzbekistan, 2017, No. 6, Article 70

2. Alisher Navoi, Махбуб ул-кулуб (Love of hearts). - Tashkent, Publishing house of Literature and Art named after G. Gulam. 1983. -105 p.

3. A. Usmonkhodjaev. The Spirituality of Health Workers, - Tashkent, 2014, "New Generation", page 276.

4. Bekmirzaev I. Spirituality of the judiciary. - Tashkent: "Spirituality", 2019. 20 p.

5. Ibn Sina. Рисолаи фил ишқ...- Б. 58-59.

6. Kuldasheva G. D. Diagnostics of motivation of students of a medical institute / Modern Education. 2015, No. $9.21 \mathrm{p} /$

7. K.V. Zorin, N.V. Kudryavy, A.S. Molchanov, N.B.Smirnova, Ukolova E.M. Teacher in a changing world.Traditions and innovations. Moscow, 2001-304

8. Mustafaev Sh.N. Art and Education. - Tashkent, 2016. 52-p.

9. Nazarov K. Philosophy of Values (Axiology). -T .: The National Society of Philosophers of Uzbekistan. 2004. $-193 \mathrm{p}$.

10. Alliyarov A.D. Development of spiritual values in students of higher educational institutions. 13.00.01 pedagogical theory. History of pedagogical teachings. Thesis for the degree of Doctor of Philosophy (PHD) in Pedagogical Sciences. Tashkent, 2019. $29 \mathrm{p}$

11. Akramova Sh.A. Development of ideological immunity for future Customs officers. 13.00.01 - Theory and history of pedagogy. Thesis for the degree of Doctor of Pedagogical Sciences in Management in Education. - Tashkent, 2017. -31-p.

12. Aslonov I. N. Factors of personality-psychological training of personnel in improving the efficiency of the customs system - Abstract of Ph.D. of Psychological Sciences Tashkent. 2009.-25 p.

13. Asadov Yu.M. The individual psychological characteristics of teachers as factors in the development of professionalism Abstract of Ph.D. of Psychological Sciences Tashkent, 2007.-25 c.

14. https://ru.citaty.net/avtory/vladimir-mikhailovich-bekhterev/

15. @Mehrob_uz. Date of viewing - November 27, 2019.

16. Character Education - ERIC Resources [Electronic resource]. - URL: www.indiana.edu (date of reference:15.03.2018). 